\title{
Ku redefinicji ludobójstwa: realia lokalne
}

Dennis Klein (Kean University, New Jersey, USA)

Lokalny charakter ${ }^{1}$ ludobójstwa staje się przedmiotem coraz większego zainteresowania wśród badaczy dociekających istoty tego zjawiska. Lokalność-rozumiana tutaj przede wszystkim w kontekście relacji świadków-otwiera perspektywę pozwalającą zrewidować znaczenia tradycyjnie przypisywane ludobójstwu. Ponadto, daje ona możliwość przedłożenia alternatywnego obrazu dynamiki, jaka dokonuje się w lokalnej społeczności po dokonaniu aktu ludobójstwa. Po pierwsze, badania prowadzone nad lokalnymi aktami masowego mordu wykazują, że czyny te są często poprzedzone decyzjami, a także intencjami unicestwienia i zagłady. To zaś pozwala zakwestionować standardową definicję „zamiaru dokonania zagłady", włączoną do art. 2 Konwencji ONZ w sprawie zapobiegania i karania zbrodni ludobójstwa. Po drugie, analiza narracji świadków z jednej strony, sprawców zaś z drugiej daje przesłankę po temu, by postrzegać sprawców zbrodni ponad ich zbrodniami i wytyczać ścieżkę wiodącą do zadośćuczynienia po ludobójstwie. Zazwyczaj ludobójstwo oznacza systematyczny atak z premedytacją, tak dalece haniebny, że niszczy on trwale honor jego sprawców. Dzięki ponownie dokonanej analizie ludobójstwa jako konstelacji mikro-morderstw może się jednak okazać, że zamiast częstych improwizacji, których zbrodniczość niemal poraża świadków, rozpoznać można powinowactwo między sprawcami przestępstwa.

\section{Najeźdźcy i konsekwencje improwizacji}

Wystarczy spojrzeć na przypisy do przełomowego, traktującego o ludobójstwie rozdziału w książce Rzq̨dy państw Osi w okupowanej Europie autorstwa Rafała Lemkina (1944), by uzmysłowić sobie, że jego sformułowanie pojęcia ludobójstwa rozumianego jako „skoordynowany plan” opierało się na lekturze źródeł stworzonych przez elity narodowego socjalizmu (Lemkin 1944, 79-82). Jego uważne studia nad niemiecką filozofią ludobójstwa odzwierciedlały też inne współczesne badania takich prześladowań. Na przykład Konrad Heiden pisał w 1939 r. o „nazistowskim

${ }^{1}$ The paper appeared in its original English version under title Locality and the Hidden Realities of Genocide in Historical Reflections/Reflexions Historiques 39(2)/2013): 3039. The Polish translation presented here is based on the original unpublished manuscript (c) for the Polish translation by Ethics in Progress Quarterly. (c) for the English version by Dennis Klein. 
przywództwie” i jego determinacji w umożliwianiu niemieckim Żydom „cichej śmierci" (Heiden 1939, 172). Przyglądając się architektonice ludobójstwa z metaperspektywy dostrzegamy, że kanoniczna dla takiej optyki jest procesualność, ogromna skala i oderwanie od podstawowych faktów. Jest to złożona narracja, skoncentrowana wokół mordu dokonanego w obozach zagłady na skalę przemysłową. Auschwitz stał się symbolem destylacji. Paradygmat ten legitymizuje motywy widoczne gołym okiem: propagandę państwową, władzę totalitarną, ideologiczną lojalność. Ludobójstwo opiera się na przesłance, że zabijanie jest wykalkulowane i dokonywane z premedytacją.

W swoich badaniach z 2006 r. dotyczących powojennej Europy Tony Judt odzwierciedla koncepcyjne zmiany w tym przedmiocie. Stara się uchwycić lokalną, oddolną ewolucję rozwoju wydarzeń wojennych. W jego ocenie współpraca mieszkańców umożliwiła zagładę w Norwegii, Belgii, Holandii i Francji - w rzeczywistości, w której Europejczycy nie tak łatwo przyznawali się do swoich czynów, nie tylko z uwagi na możliwość obwinienia czy oskarżenia, lecz także dlatego, że inne okoliczności, włącznie z ich własnymi cierpieniami wojenne, stratami i próbami powrotu do normalności były dla nich najważniejsze (Judt 2006, 803-31; Friedländer 2007). To monumentalne studium odbiega daleko od głównego nurtu badań nad „oficjalnym” ludobójstwem, mającego znikome związki z pojęciem, którym Judt określa „odpowiedzialnością zbiorową" (Kuper 1982; Judt 2006, 811). Lee Ann Fujii w swojej książce z 2009 r., zatytułowanej Killing Neighbors: Webs of Violence in Rwanda, stwierdziła, że akty zabijania kiełkują na poziomie życia codziennego, który nazywa „mikrohistorycznym” lub „mikropolitycznym”: „Przemoc na peryferiach nie zawsze podąża za główną narracją elit z centrum". Ten "mikropolityczny zwrot w badaniu społecznej przemocy" jest również przedmiotem innych, świeższych badań nad aktami ludobójstwa w w Hercegowinie, Kambodży i Rwandzie. Kładzie jednak nacisk na Holocaust jako najistotniejszy przypadek studium mordu lokalnego (Bacirevic 2009; Bringa 1993; Hinton 2004; Fujii 2009; Strauss 2006; McDoom 2009).

Wpływowa polemika Jana Grossa, podjęta przezeń w książce pt. Sąsiedzi: historia zagłady żydowskiego miasteczka, poświęcona została chyba najbardziej dramatycznemu przypadkowi mordu lokalnego. Ponadto, autor podejmuje $\mathrm{w}$ niej próbę charakterystyki ludobójstwa jako czynu intencjonalnego. „Bardzo dobrze wiemy, że dla zgładzenia milionów ludzi potrzeba sprawnej biurokracji wraz $\mathrm{z}$ (relatywnie) zaawansowaną technologią. Jednak morderstwo na Żydach w Jedwabnem odkryło inną, głębszą i bardziej archaiczną warstwę przedsiębiorczości" (ibid.) w tej materii. Opowiedziana przez niego historia zdaje się przeczyć intuicji: pewnego letniego dnia w lipcu 1941 r. Polacy z Jedwabnego, mieszkający w zgodzie ze swoimi żydowskimi sąsiadami znający ich z imienia wymordowali ich niemal co do jednego. Gross dostrzegł w tej zbrodni pewną cechę wyróżniającą, mianowicie „brak organizacji”. Trudno o bardziej przekonującą ilustrację tego, 
że Zagładę rozważać należy równocześnie na dwa sposoby. Z jednej strony trzeba umieć o niej mówić jako o systemie, który funkcjonował wedle z góry ułożonego (choć ulegającego ciągłym modyfikacjom) planu. Trzeba jednak pamiętać, że była to również (a być może przede wszystkim) mozaika, na którą złożyły się oddzielne epizody, improwizacje lokalnych kacyków, a także niewymuszone odruchy i zachowania ze strony otoczenia.

Eskalacja morderstwa masowego nie jest zupełnie spontaniczna. Ma swoje określone warunki wstępne. Polacy w tej małej wiosce przećwiczyli narodową narrację, opartą na wspomnieniach tworzących zbiorową traumę, w którą zamieszani byli również Żydzi. Doświadczyli jej niedawno, podczas brutalnej, dwuletniej okupacji sowieckiej-wspieranej, jak wierzyli, przez miejscowych Żydów-zanim naziści zerwali swój alians z Sowietami w czerwcu 1941 r. i wydalili ich [Sowietów]. Eva Hoffman twierdzi ponadto, że więzi międzysąsiedzkie były znacznie luźniejsze niż mogłoby się wydawać: „Przed wojną bowiem większość Polaków i Żydów nie włączała się kręgi naturalnych zobowiązań wzajemnych“. Relacje te odznaczały się niejaką "bliskością i zaangażowaniem”, lecz nie było w nich „bezpośredniej wymiany i zażyłości". Teza Hoffman znalazła poparcie w wypowiedzi jednego z mieszkańców Jedwabnego z okresu wojennego, Jerzego Laudańskiego, który zauważył, że „żyliśmy razem przez kilkaset lat i nie było między nami różnic”. Jednakże na pytanie, „czy odwiedziłeś kiedyś żydowski dom?” odpowiedział on: „nie, tak daleko nie zaszedłem”. Sam Gross, pomimo zapewniania o istnieniu dobrosąsiedzkich stosunków, zaobserwował [w miejscowych narracjach] od dawna „skrywane” napięcia, takie jak rozpowszechnione wśród Polaków przekonanie, jakoby Żydzi praktykowali mord rytualny i byli zabójcami Chrystusa. Żydzi nieustannie obawiali się nadchodzącego pogromu (Hoffman 1997, 247, 161; Bikont 2004, 277; Gross 2001, 18-19, 38). W dodatku, jak zauważyli Daniel Bar-Tal i Keren Sharvit, nazistowska inwazja zaogniła niestabilne warunki; mowa tu o „kontekście przejściowym”, który doprowadził do ekstremalnych zachowań Polaków wobec swoich żydowskich sąsiadów (Bar-Tal \& Sharvit 2008, 150-51; Eckmann 2011). Jednak warunki te pozostawały nieuświadomione lub przynajmniej podświadome, co z kolei oznacza, że nie mogły doprowadzić aktów zabijania [bezpośrednio]. Nie naświetlają one kontekst, a raczej pewne bezpośrednie li tylko okoliczności, które pomimo swojej chaotyczności stały się bodźcem dla nieplanowanych działań.

Badania nad ludobójstwem w Rwandzie ilustrują powyższą tezę. Hutu, pomimo że ich rywalizacja o władzę z Tutsi była historycznie bardzo intensywna, często działali w sposób nagły i błyskawiczny, przeistaczając się ze zwykłych gapiów w morderców lub ratowników. Jak zauważa Fujii, taka transformacja ma naturę „endogeniczną”, ponieważ zachodzi immanentnie w trakcie rozwoju dramatu: „Niejednoznaczności i sprzeczności były głównymi cechami przemocy na obszarach wiejskich" (Fujii 2009, 8, 85-88). Jej kontekst 
był czysto instrumentalny. W świetle publicznego ujawnienia wydarzeń okazywało się, że jednostki były przyciągane i odpychane przez różnych napastników. Przyłączały się albo jako „sprzymierzeńcy" w zbrodni albo jako wykonawcy. Jednak „za kulisami” owo przyłączający się nie zabijali na własną rękę, z własnej inicjatywy. Nieraz podejmowali decyzję, by pomóc lub ocalić Tutsi. Krótko mówiąc, przemoc oznacza „możliwość stworzenia 'nowego człowieka'”. Zabijanie zaś rodzi się w ferworze wydarzeń (Fujii 2009, 8, 8588).

\section{Świadkowie. Konsekwencje uznania}

Uwaga badawcza skupiona na lokalności pozwoliła ukazać drugi problem związany z intencją resp. zamiarem ludobójstwa. W rekonstrukcji wydarzeń uczeni poświęcają coraz więcej uwagi zeznaniom świadków lub ofiar, rozumianych jako korpus źródeł uzupełniających, a niekiedy konkurencyjnych wobec rejestrów państwowych $\mathrm{w}$ trakcie publicznej prezentacji procesu zagłady. Oczywiście niektórzy historycy zakładają powojenną kategorię „wieku świadka” (Weviorka 2006). Istotne są konsekwencje tych badań. Wielu świadków traktuje napaść w sposób osobisty. Wykazują, że znali swoich oprawców. W rzeczywistości byli sąsiadami, acz nie zawsze przyjaciółmi; stanowili jednak wspólnotę. Nawet w Europie Zachodniej, gdzie masowe mordy były regułą, ofiary i zabójcy uznawali siebie za rodaków lub członków populacji ludzkiej. To zupełnie nowa informacja dla wielu współczesnych badaczy, którzy łatwo mogą przeoczyć szczegóły codziennego bytowania nieznanej im przecież społeczności lokalnej. Jednak zrozumienie międzykulturowego wymiaru napaści pomaga nam dostrzec, że świadkowie w swoich „oddolnych", osobistych relacjach z wydarzeń opisują nie tylko okoliczności przemocy, lecz także czynniki tych starć, zatem również pogwałcenie zaufania społecznego. W rzeczy samej, z badań wyłania się problem zdrady, który można usytuować w samym sercu procesu zagłady.

Ofiary opisujące zdradę postrzegają najeźdźców nie tylko jako przestępców, których oskarżają we wszystkich swoich zeznaniach (co jest tutaj głównym tropem), lecz także jako osoby, jako swych rodaków i sąsiadów. Twierdzenie Hoffmana, że $w$ relacjach sąsiedzkich nadal dominuje emocjonalny dystans, nie umniejsza rangi zdrady, której doświadczały i którą opisywały ofiary. Nawet jeśli sąsiedzi nie pozostawali w przyjacielskich stosunkach, ofiary często sobie tego życzyły i miały poczucie, że tak właśnie jest. W ich oczach najeźdźcy nie byli po prostu zabójcami z zamiarem zagłady, aczkolwiek traumatyczna natura tych realiów łatwo przesłania inne wspomnienia o nich, przechowywane $\mathrm{w}$ pamięci. Równolegle $\mathrm{z}$ badaniami prowadzonymi nad złagodzeniem wyroku kary śmierci, relacje świadków dostarczają takiego materiału dowodowego o najeźdźcach, że osłabia on 
charakterystykę tych ostatnich jako jednowymiarowych, intencjonalnych zabójców.

Ilustracje dla tego, jak rzeczywiście wyglądało wzajemne uznawanie się, znajdziemy we współczesnych badaniach nad zbiorowymi masakrami na terenie Europy Wschodniej podczas II wojny światowej. Jak ustalił historyk Omer Bartov (2007), Ukraińcy, Polacy, jak i Żydzi „żyli obok siebie w Galicji Wschodniej przez blisko czterysta lat. Grupy te znały tylko rzeczywistość współistnienia" (ibid. 115-116). W życiu zawodowym, w domu wśród sąsiadów, razem świętując i wzajemnie się wspierając, na targowiskach i w miejscach pracy, w szkołach, a nawet w służbie państwowej i wojskowejmieli oni ze sobą nieustanny kontakt.

Co ważne, grupy niemające udziału w strukturach władzy interpretowały warunki lokalnego życia odmiennie aniżeli grupy znajdujące się strukturach władzy. Jak wyjaśnia filozof polityczny Hannah Arendt, „Żydzi zupełnie ignorowali narastające napięcia między państwem i społeczeństwem”. Byli „ostatnimi, którzy uświadomili sobie, że okoliczności przymusowo postawiły ich w epicentrum konfliktu". Albo też, jak sugestywnie komentuje historyk Saul Friedländer, „Żydzi byli nieświadomi tego, że »Żyd» jest wykluczony z domeny naturalnych czy umownych relacji bądź zobowiązań" (Friedländer 2007, 10; Arendt 1973; 1978). Ich przywiązanie do własnych sąsiadów było niezachwiane nawet wówczas, gdy okazywało się być złudne. Postrzegali te więzi jako obiecujące i gwarantujące względnie bezpieczną koegzystencję. Wierzyli, a raczej chcieli wierzyć, że uchroni ich to przed skrzywdzeniem. Ale ich najgłębsze nadzieje zostały zawiedzione. Spodziewali się ochrony nawet wówczas, gdy ich relacje zaczęły się znacznie pogarszać z końcem XIX wieku, kiedy to „cudzoziemskie" grupy zaczęły być wykluczane z rozmaitych korzyści i możliwości. Jan Błoński odnotował o tych okolicznościach, które pojawiły się w owym czasie w Polsce, co następuje: „Były tam, uświadomione lub nie, oczekiwania pokładane w tym, że ich los się poprawi, że ciężar upokorzenia się zmniejszy, a przyszłość stanie się stopniowo coraz jaśniejsza. To, co się wydarzyło, było dokładnym przeciwieństwem ich oczekiwań" (Polonsky \& Michalic 2001, 13). W okresie międzywojennym Żydzi w Europie Wschodniej traktowani byli jak bandyci, którzy podczas okupacji sowieckiej w latach 1939-41 mieli zawrzeć diaboliczny sojusz z przerażającymi komunistami. Jak opisuje to Bartov, lokalni mieszkańcy widzący w sobie zarówno sąsiadów, jak i wrogów, stworzyli schizofreniczną etnografię (Bartov 2008,117).

Ofiary postrzegały swoich sprawców w sposób dwojaki, co manifestowało się jako silne wspomnienie o swoich najbliższych sąsiadach, nawet wówczas, gdy ujawniono już ich zbrodnicze postępki. Nawet w 1944 r., zniewolony w murach getta warszawskiego Emanuel Ringelblum, kronikarz Zagłady, tak ilustrował wytrwałość i niezłomność oczekiwań: „Czy to było nieuniknione, że Żydzi ... mają doświadczyć obojętności, a nawet radości na twarzach swoich sąsiadów?" (Ringelblum 1992, 7-8). Relacje świadków o 
napaściach często rozpoczynały się od szoku w obliczu rozpoznania. Jeden ze świadków, kobieta wspominająca masakrę, jaką obserwowała z nieodległej kryjówki, zaznaczała, że ofiary „znały tych ludzi”-tj. ukraińskich policjantów-i po tym, jak zostali zdemaskowani, odkryła wśród nich siedmiu swoich krewnych. Zeznała, że „zapowiedzieli im ... »nic wam nie zrobimy, tylko dajcie nam wszystko co macie i puścimy was wolno». Oddali im wszystko, a kiedy już wyszli, każdy jeden dostał strzał w głowę". Jeszcze bardziej wstrząsające były jej zeznania dotyczące aresztowania w $1942 \mathrm{r}$. Oficer policji „był ojcem mojej przyjaciółki Olgi, człowiekiem, który przed wojną obejmował mnie i całował", mówiąc, że jestem dla niego niczym córka. Teraz był „ukraińskim policjantem, który przyszedł z Niemcami do getta, żeby nas pozabijać" (Bartov 2008, 13-14).

Zeznania Jeana Améry`ego, austriackiego Żyda, który opuścił ojczyznę, by przystąpić do ruchu oporu w Belgii, przedstawiają wgląd w pojęcie zdrady i, co ważniejsze, w jej elementarny paradoks, polegający na możliwości zobaczenia przez ocalałych swoich oprawców niezależnie od okoliczności popełnianej zbrodni. Wspomnienia Améry`ego, w kontekście wszystkich jego filozoficznych rozważań, mają silnie osobisty wyraz. Jak już wspomniałem (Klein 2011), spisywał on swoje pamiętniki w formie dialogu $\mathrm{z}$ rodakami, którzy, jak twierdził, całkowicie złamali zasady umowy społecznej (Améry 1980, 40). Jego zapiski pochodzą z cyklu audycji radiowych z 1964 r. W audycjach tych mówił, a później także pisał o tych sprawach bezpośrednio do swoich niemieckich kolegów. Odnosił się po imieniu do tych, którzy go torturowali i opisywał nie tylko „policyjną pięśc”, lecz także ich twarze, które były dla niego „znajome” (ibid. XIV, 29, 70-71, 31-32). Améry odkrywczo opisuje swoich oprawców jako „bliźnich”, którzy, co wyraża z charakterystyczną goryczą, stali się jego „wrogami” (ibid. 28).

Améry uważany jest za mistrza w chowaniu urazy, za świadka, który pomimo upływu czasu i nacisków społecznych, aby „ruszyć do przodu i nie oglądać się za siebie" odmówił zwolnienia najeźdźców i współziomków od poczucia winy (Brudholm 2006, 20; Brudholm 2008). Jego narracja uznania podtrzymuje ściganie zbrodniarzy, a także ich niemieckich potomków, zmieniając ten proces $\mathrm{w}$ requiem złamanego zaufania na świecie. Wspomina on tragizm naiwnego oczekiwania „pomocy” nawet wówczas, gdy wraz z innymi został złapany i był torturowany przez gestapo (Améry 1980, 28). Ale jest to również element kontemplacyjny, mający moc przekształcenia świadectwa pogardy i niechęci w coś dynamicznego, graniczącego z zadośćuczynieniem.

Podstawa tej łukowatej konstrukcji [przebaczenia] jest dostrzegalna jedynie we fragmentach elegii o skrajnej samotności. Ocaleni często wycofywali się ze świata, któremu nie potrafili już zaufać. Jednakże, jak wyznał Améry, cena którą musieli za to zapłacić była nie do udźwignięcia: „Stawką jest uwolnienie od poczucia odrzucenia, które tkwi we mnie 
od tamtego czasu, aż do dziś" (ibid. 70). Ta i podobne obserwacje stały się impulsem do pracy, do odnalezienia drogi powrotnej. Renegocjacje ze zbłąkanym światem nigdy nie dają pewności, lecz sama ich potrzeba, samo pragnienie jest bardzo silne, wręcz „euforyczne”, przepełnione chęcią komunikacji i wysiłkiem osiągnięcia pojednania. Nie powinniśmy zapominać o tym, że mówienie do niemieckich kolegów i pisanie pamiętników jest istotnym źródłem nowych możliwości, które pozwolą zbrodniarzowi „dostrzec w ofierze drugiego człowieka" (ibid. 72).

Inni, mający odwagę pisać wspomnienia, poszukują punktu, w którym dostrzec można $\mathrm{w}$ najeźdźcach człowieczeństwo. Jest to bardzo skomplikowane: jak bowiem połączyć znamiona ludobójstwa $\mathrm{z}$ przynależnością sprawców do gatunku ludzkiego? Przynależność ta zdaje się być osłabiona. Szymon Wiesenthal, dobrze znany z dążności do pociągnięcia byłych nazistów do odpowiedzialności karnej, wskazuje na pouczający przykład. W swoim pamiętniku Słonecznik (1969) wspomina on wydarzenie z 1942 r., które miało miejsce podczas jego pobytu w getcie. Wyznaczono go na służącego dla umierającego oficera SS. Oficer ten, leżąc już na łożu śmierci, poprosił Wiesenthala o wybaczenie. Historia ta sprowokowała dyskusję pełną pytań o prawdziwość tej dziwacznej prośby, złożonej przez umierającego katolika, który nie prosił o ostatnie sakramenty, lecz o wybaczenie ze strony Żyda. Wiesenthal utrzymywał, że w pierwszym odruchu owszem, rozważał przebaczenie oficerowi, ostatecznie jednak nigdy się na to nie zdobył (Segev 2010, 229-40). Godna szczególnego odnotowania jest jego decyzja, która pozostaje sednem historyczności tego, czego doświadczył osobiście: jeśli żadne inne zdarzenie tyle dla niego nie znaczyło, to odzyskał on w jakimś sensie symboliczne poczucie równowagi. Jest to bowiem $\mathrm{w}$ ostatecznym rozrachunku świadectwo sposobu, w jaki Wiesenthal decyduje się wspominać tych, którzy dopuścili się niewyobrażalnych zbrodni.

Podobnie jak Améry, Wiesenthal podkreśla, jak bardzo znajome były mu przerażające okoliczności. Mimo, że nie znał Karla, owego oficera SS, to po raz pierwszy zobaczył go w technikum, do którego uczęszczał przed wojną i które naziści przekształcili później w szpital wojskowy. Dla niego rozmowa z tym Niemcem w pokoju, który kiedyś był dziekanatem, dobrze rozpoznawalnym z dziedzińca i ulicy prowadzącej do szkoły-która teraz stała się jego via dolorosa - okazała się być niewyobrażalnym ciosem. To było tak, jakby planeta ludzkiej wspólnoty została nagle zaćmiona przez masową zbrodnię.

Nawet we wspomnieniach o swoim spotkaniu z wrogiem Wiesenthal nie umniejszał brutalności nazistów. Otwarcie mówił o popełnionych przez Karla, skrajnych zbrodniach i jego wyraźnych zamiarach. Karl otrzymywał rozkazy, które wykonywał świadomie lub, jak sam mówił: „»Mieliśmy karabiny, przygotowane do zastrzelenia każdego, kto próbował uciec» z domu, w którym zbierali się Żydzi. »I strzelaliśmy« ...” (Wiesenthal 1988, 42-43). Jednakże Wiesenthala bardziej interesował Karl aniżeli jego czyny, co 
uwidoczniło się w jego opowieściach o nieuchronnie rodzącej się między nimi, powściągliwej zażyłości. Przytoczył doznania, które potwierdziły ich ludzkie relacje-na przykład uczucie, gdy Karl spoglądał na niego oczyma całkowicie ukrytymi pod bandażami; albo wrażenie, jakie na nim wywarł, wspominając dziecko o »ciemnych oczach«, wyskakujące z płonącego budynku.

Wiesenthal silnie argumentował na rzecz łagodniejszego traktowania sprawców. W końcowych partiach swego pamiętnika wspomina podróż, którą odbył po wyzwoleniu w poszukiwaniu matki Karla. Chciał $w$ ten sposób uzyskać „jaśniejszy obraz [jego] osobowości” i w, rzeczy samej, studiował jego zdjęcie, szczególną uwagę zwracając na „oczy, których nigdy nie ujrzał” (ibid. 84, 86). W swym pamiętniku Wiesenthal przyznaje, że darzył Karla „współczuciem”, którego nic nie mogło rozwiać, pomimo usilnych prób uznania nazistów za sprawców „potwornych” zbrodni, godnych najsroższej kary. Zjawisko to można określić mianem „schizofrenicznego” profilu wroga. W ocenie Wiesenthala Karl był „mordercą, który nie chciał być mordercą, lecz został stworzony mordercą za sprawą morderczej ideologii". Podkreśla to trzykrotnie: „Nie urodził się mordercą i nie chciał się nim stać”; „Karl był z pewnością »dobrym chłopcem ". Ale ten okrutny czas zmienił go w mordercę" (ibid. 53, 66, 95). To, co na co sobie pozwalał w wyobraźni, potwierdza wcześniej przez nas opisywany fakt historyczny, że Żydzi darzyli swoich sąsiadów zaufaniem, licząc na ich pomoc, gdy będą w potrzebie. Stanowiło to podstawę ich związków, „zażyłości”, a niewykluczone, że także „osobistej więzi ... między mordercami i ich ofiarami" (ibid. 92, 15, 7). Nawet wówczas, gdy ich świat się rozpadł, Żydzi zachowali zdolność do potrzymania swojej post-emancypacyjnej ufności w trwanie wspólnoty ludzkiej jako wspólnoty człowieczeństwa.

\section{Redefiniując ludobójstwo}

Relacje świadków wywarły wpływ na wnioski płynące z rozważań nad radykalną zbrodnią, jaką jest ludobójstwo. Ustalenie zamiaru przestępczego i stawianie sprawców przed wymiarem sprawiedliwości pozostaje fundamentalną procedurą, służącą przywróceniu równowagi moralnej. W rzeczy samej, ocaleni przedstawili dowody obciążające przeciwko działalności przestępczej sprawców, co umożliwiało egzekucję surowszych kar. Jednak momenty pojednania i przebaczenia do niedawna jeszcze przewijały się w pracach rozmaitych komisji historycznych, zajmującymi się badaniem zbrodni ludobójstwa. W swoich wspomnieniach ofiary ocalałe z Holocaustu z trudem potrafią przywołać ludzi zobowiązanych do potwierdzenia zeznań świadków z innych miejsc. W Rwandzie trybunał Gacaca, w RPA z kolei Komisja Prawdy i Pojednania (TRC), jak powiedziałby Desmond Tutu, zadaje sobie trud dążenia do narodowego pojednania. Echo dialogów podejmowanych z wrogami przez Améry'ego i Wiesenthala można usłyszeć w słowach wypowiedzianych przez 
Pumlę Gobodo-Madikizeli, członkinię TRC, biorącą udział w publicznych przesłuchaniach w Prowincji Przylądka Zachodniego. Mogła ona obserwować proces przebaczania sprawcom ze strony ofiar „od momentu, gdy tylko miały one okazję spotkać się z tymi, którzy zgotowali im taki ogrom bólu i cierpienia" (Gobodo-Madikizela 2004, 98; zob. też Krog 1999, 165-67).

W Australii, Nowej Zelandii, Anglii i Stanach Zjednoczonych we wczesnych latach 90-tych XX w. pojawił się ruch zwany Restorative Justice. Rzucił on wyzwanie konwencjonalnemu prawu karnemu i zaostrzaniu kar, a także tendencji do podkreślania roli zadośćuczynienia. Choć jego pierwotnym założeniem było obniżenie liczby recydywistów, zainteresował się on także ofiarami. Podczas konferencji organizowanych przez Ruch skupiano w jednym miejscu ofiary i ich oprawców, dając tym pierwszym szansę dostrzeżenia u swoich oponentów czegoś więcej niż brutalność. Przeprosiny lub wyrażenie wstydu mogą stanowić punkt wyjścia dla formowania się „więzi emocjonalnej", która ma szansę przerodzić się we współczucie, miłosierdzie, a nawet w „zdolność do przebaczenia” (Strang 2002). Celem działalności ruchu nie jest wypieranie środków karnych, lecz sprawienie, aby przestępcy zyskali "twarz". To zaś bywa ignorowane w standardowych procedurach systemu sprawiedliwości.

Branie pod uwagę lokalnych okoliczności skłania do tego, by przeformułować pojęcie ludobójstwa. Podkreślenie pierwotnej eskalacji ataku rzuca światło na to, że zamiar-choć stanowi warunek konieczny ludobójstwa - nie zawsze jest jego warunkiem wystarczającym. To zaś podważa definicyjną ortodoksję w pojmowaniu masowego mordu. Lokalność zakłada branie pod uwagę również przekonań świadków co do tego, że choć popełnione zbrodnie nie znajdują usprawiedliwienia i domagają się kary, to ład zaprowadzony po ludobójstwie może otwierać możliwość międzyludzkiego pojednania.

Z jęz. angielskiego przełożyła Marta Zuzanna Huk

\section{Literatura}

Améry, J. 1980. At the Mind's Limits: Contemplations By a Survivor on Auschwitz and Its Realities. Bloomington: Indiana University Press.

Arendt, H. 1973. The Origins of Totalitarianism. New York: Harcourt, Brace \& Co.

Arendt, H. 1978. The Jew As Pariah: Jewish Identity and Politics in the Modern Age. Ed. R. H. Feldman. New York: Grove Press. 
Bar-Tal, D. \& Sharvit, K. 2008. "The Influence of the Threatening Transitional Context on Israeli Jews' Reactions to Al Aqsa Intifada." In Esses, M. \& Vernon. R.A. (Eds.), Explaining the Breakdown of Ethnic Relations Why Neighbors Kill. Oxford: Blackwell Publishing.

Bartov, 0. 2008. Testimonies As Historical Evidence: Reconstructing the Holocaust from Below (unpublished manuscript).

Becirevic, E. 2009. Na Drini Genocide [Genocide on the Drina River]. Sarejevo: Memorija Library.

Bikont, A. 2004. "We of Jedwabne." In Polonsky, A. \& Michlic, J.B. (Eds.), The Neighbors Respond: The Controversy Over the Jedwabne Massacre in Poland. Princeton, N.J.: Princeton University Press.

Bringa, T. 1993. We Are All Neighbors. Publishing Broadcasting Service, directed by D. Christie, D., Caird, R., \& Wason, D.

Brudholm, T. 2008. Resentment's Virtue: Jean Améry and the Refusal to Forgive. Philadelphia: Temple University Press.

Brudholm, T. 2006. "Revisiting Resentments: Jean Améry and the Dark Side of Forgiveness and Reconciliation." Journal of Human Rights 5: 2006.

Eckmann, M. 2011. "Psychosocial Dimensions in Extreme Neighborhood Violence." In »Intimate Killing»: Reassessing the Intent to Destroy (paper presented at the conference Contextual View of Genocidal Intent, University of Leicester, U.K., September 22, 2011).

Friedländer, S. 2007. The Years of Extermination. New York: Harper Collins Publishers.

Fujii, L. A. 2009. Killing Neighbors: Webs of Violence in Rwanda. Ithaca: Cornell University Press.

Gobodo-Madikizela, P. 2004. A Human Being Died That Night: A South African Woman Confronts the Legacy of Apartheid. Boston: Houghton Mifflin.

Gross, J. T. 2001. Neighbors: The Destruction of the Jewish Community in Jedwabne, Poland. Princeton: Princeton University Press.

Heiden, K. 1939. The New Inquisition. Trans. H. Norden. New York: Modern Age Books, Inc. and Alliance Book Corp.

Hoffman, H. 1997. Shtetl: The Life and Death of a Small Town and the World of Polish Jews. Boston: Houghton Mifflin.

Judt, T. 2006. Postwar: A History of Europe since 1945. New York: Penguin Press.

Klein, D. 2011. "Resentment and Recognition: Toward a New Conception of Humanity in Améry's At the Mind's Limits." In Zółkoś, M. (Ed.), On Jean Améry: Philosophy of Catastrophe. Lanham, Md.: Lexington Books.

Krog, A. 1999. Country of My Skull. London: Jonathan Cape.

Kuper, L. 1982. Genocide: Its Political Use in the Twentieth Century. New Haven: Yale University Press.

Laban Hinton, A. 2004. Why Did They Kill?: Cambodia in the Shadow of Genocide. Berkeley: University of California Press. 
Lemkin, R. 1944. Axis Rule in Occupied Europe. Washington: Carnegie Endowment for International.

McDoom, 0. 2009. "The Micro-Politics of Mass Violence: Security, Authority, and Opportunity in Rwanda's Genocide." Unpublished PhD dissertation, London School of Economics.

Ringelblum, E. 1992. Polish-Jewish Relations During the Second World War. In Kermish, J. \& Krakowski, S. (Eds.). Evanston, IL: Northwestern University Press.

Segev, T. 2010. Simon Wiesenthal: The Life and Legends. New York: Doubleday.

Strang, H. 2002. Repair or Revenge: Victims and Restorative Justice. Oxford: Oxford University Press.

Strauss, S. 2006. The Order of Genocide: Race, Power, and the War in Rwanda. Ithaca: Cornell University Press.

Wiesenthal, S. 1998. The Sunflower: On the Possibilities and Limits of Forgiveness. New York: Schocken Books.

Wieviorka, A. 2006. The Era of the Witness. Ithaca: Cornell University Press. 
Dennis Klein (New Jersey, USA)

\author{
Ku redefinicji ludobójstwa: realia lokalne \\ Re-defining Genocide: Locality Context
}

\begin{abstract}
Looking at local circumstances such as a neighborhood compels a reformulation of genocide. Their exposure of the incremental escalation of assault makes clear that intention, though a necessary condition of genocide, isn't always a sufficient one, eroding the orthodox definition of genocide itself which too evolves. Locality also takes into account witnesses' conviction that, though the commission of radical crimes is indefensible and demands prosecution, a post-genocide order can accommodate a human synthesis as well as a post-traumatic coexistence of peoples.
\end{abstract}

Keywords: Holocaust, re-defining genocide, locality, neighborhood, restorative justice.

Doi: 10.14746/eip.2014.2.17 